\title{
Value Capture from Social Capital in Executive Search
}

\author{
Vlatka Skokic ${ }^{1} \&$ Marko Coh $^{2}$ \\ ${ }^{1}$ Faculty of Business, Economics and Law, University of Surrey, UK \\ ${ }^{2}$ Maxxim Consulting, UK \\ Correspondence: Vlatka Skokic, Faculty of Business, Economics and Law, University of Surrey, GU2 7XH, \\ Guildford, UK. Tel: 0044-1-483-689-758. E-mail: v.skokic@ surrey.ac.uk
}

Received: June 24, 2015

Accepted: July 15, 2015

Online Published: August 25, 2015

doi:10.5539/ ibr.v8n9p47

URL: http://dx.doi.org/10.5539/ ibr.v8n9p47

\begin{abstract}
The theme of this article is value capture in the context of executive search. We build on literature in economic sociology and organisational theory that demonstrates that relationships contribute to creation of economic value and addresses how thus-created economic value is distributed amongst participants in transactions. In our context transactions consist of search firm commencing a concluding searches for appropriate candidates for executive vacancies at hiring firms. This research examines what kinds of pre-existing relationships with candidates enable search firms to complete searches quicker and thus capture more value. It derives hypotheses from literature on learning and socialisation in relationships, and tests them with a sample of 924 searches conducted by a global executive search firm between January 2005 and May 2009. We found evidence of learning in relationships that supports value capture (with delayed effect). Specifically, value captured due to relationship-based learning can be almost half greater than when there is absence of such learning. Our findings extend the literature on value creation and value capture through relationships and demonstrate that value may be captured in situations that are not strictly competitive. We discuss the limitations of our study and indicate how the combination of findings and limitations opens avenues for future research.
\end{abstract}

Keywords: executive search, fixed effects regression, learning, panel data, relationships, trust, value capture

\section{Introduction}

Scholars have long been interested in economic value, i.e. the monetary value of a good or service to an economic actor. One line of work, associated with economic sociology and organisational theory, has provided rich body of evidence that highlights the role of relationships between economic actors in creation of economic value in transactions. Researchers have demonstrated that specific patterns of relationships can aid in getting a job (Granovetter, 1973), improve probability of survival and loan conditions (Uzzi, 1996, 1997, 1999) and improve probability of repeat exchanges (Gulati, 1995). Relationships have also been shown to play an important role in generation of economic value in labour markets and workplace more broadly. Workers who have joined organisations via referrals, as opposed to other means, have been shown to stay longer and perform better (Fernandez, Castilla, \& Moore, 2000; Castilla, 2005; Petersen, Saporta, \& Seidel, 2000). Jointly, these studies make a compelling and empirically rigorous case for the argument that relationships directly affect the magnitude of economic value that is generated in economic transactions.

Whilst the question, 'do relationships contribute to creation of economic value?' has received significant and substantial attention in the literature cited above, less is known about how thus-created economic value is distributed amongst participants in transactions. Extant literature suggests that on the whole transactions based on pre-existing relationships among actors are economically beneficial and generally do not create significant offsetting costs for parties to the transactions. The question remains as to whether some actors capture more value that is generated than others, and if that is the case, how does that happen? This question has received little treatment in the literature and hence remains a research gap. This article endeavours to address that gap. Specifically, the article focuses on what drives value capture in transactions based on pre-existing relationships. Even though this is a rarely addressed question, there is evidence in recent literature that some parties in transactions based on pre-existing relationships capture significant value (Fernandez-Mateo, 2007; Bidwell \& Fernandez-Mateo, 2010). There is thus a case to explore how value capture materialises in more detail and that is what is addressed below. 
This article addresses value capture by executive search firms. Executive search is a process that takes place in the recruitment market for executives, where executive search firms, acting as agents of the firms hiring into executive positions, source candidates for vacancies. In this context, the value that executive search firms capture is associated with completing searches quicker. This research examines what kinds of pre-existing relationships with candidates enable search firms to complete searches quicker. It associates the pre-existing relationships with learning and trust. It derives hypotheses from literature on learning and socialisation in relationships, and tests them with a sample of 924 searches conducted by a global executive search firm between January 2005 and May 2009. We found evidence of learning in relationships that supports value capture (with delayed effect). We also hypothesised an effect on value capture of trust development in relationships, yet we haven't found that effect in the data.

Our findings provide four contributions to the literature on value capture: first, they provide further evidence that value capture is enabled by prior relationships between actors in the transaction. Second, they suggest that social support/trust and learning that flow through relationships may have a distinct effect on the ability of actors to capture value; in some contexts, such as our context of executive search, learning may be the key to value capture. Third, value capture may be a delayed effect of relationships developed over a period of time. Fourth, value may be captured in situations that are not strictly competitive, on the basis of a relationship with non-competitor. We discuss the limitations of our study and indicate how the combination of findings and limitations opens avenues for future research.

\subsection{Learning, Trust and Value Capture}

Study of relationships and economic value has produced a substantial body of literature. Common to various strands of this literature is that they all assume that relationships produce flows between actors that impact the outcomes of transactions (Podolny \& Baron, 1997; Podolny, 2001). The strands can be broadly categorised into information-based view and socialisation-based view. For information-based view, key flow in relationships is information. Detailed, rich information that gets produced and exchanged in relationships enables actors to learn about each other. For socialisation-based view, the key flow in relationships is social support, which may through time engender trust. In the sections below we provide more detail about the key premises of the two views. We focus on studies addressing labour markets, as this context provides the backdrop to the research presented here.

In this section we review the literature that explores how information transmitted through relationships affects labour market outcomes such as being interviewed and getting a job. The first theoretical approach is weak tie theory introduced by Granovetter (1973). This approach focuses on the strength of ties used in the process of finding a job. Granovetter argued that the ties among members of a social clique are likely to be strong (frequent and emotionally intense). Information obtained through strong ties is likely to be redundant as the individual receiving the information is likely to have that piece of information already. Information obtained through strong ties is more likely to be unique. Weak ties, in contrast, are ties between members from different social cliques, who are likely to have diverse information. Granovetter found that weak ties will be more likely than strong ties to channel timely information about job openings.

A more recent study provided robust evidence in support of the strength of the weak ties hypothesis. Yakubovich (2005) re-cast the strength of the weak ties hypothesis into a proposition about the probability of getting a job as a function of the within-actor differences in tie strength. He found that a worker's probability of obtaining a job through one of his/her weak ties was higher than the probability of obtaining it through one of his/her strong ties. Yakubovich addressed the possibility that the apparent network effects are actually a result of unobserved individual productivity. He demonstrated that the strength of the tie does have an independent effect on the probability of getting a job.

In one key study linking pre-existing relationships and information flow, Petersen et al. (2000) provided a detailed case study of hiring in a mid-sized high-technology firm in California. These authors studied the entire hiring process and found that hiring new workers on the basis of referrals from existing workers had a strong impact on the outcome of all phases of the hiring process. The authors explained that their findings indicate that some hiring channels have superior information transmission properties: "for the social networks, it is unquestionably the quality of information they yield that counts." (p. 811).

The relationship between information exchange and learning has been explicated in seminal work by Uzzi (1996, 1997, 1999). Repeated information exchange in 'embedded' networks and relationships enables parties to learn about their counter-parties in a very detailed way, which in turn enables them to adopt a really nuanced approach in economic transactions with the parties with whom they are 'embedded'.

One implication of the studies described above is that learning is a property of relationships themselves, i.e. that 
actors learn both in successful transactions and in transactions that were commenced but never completed. This property of transactions based on relationships has important implications for value capture, as we discuss below. It is also a key property of the executive search process, enabling empirical testing of our predictions.

From the perspective of information flow and learning there is a distinction between successful/completed exchanges and exchanges that were attempted but not completed. If an exchange is successful, learning can be shared, as both parties can learn why each ended up exchanging with the other. However, if exchanges are not completed, their completion must have been rejected by at least one party. If that is the case, learning becomes asymmetric: the party that rejected completion of the transaction with the other knows why they did it, but the other party may not learn (because the first party doesn't tell them, for instance). So for effectiveness of learning to take place, it does not matter only that there was a rejection of a transaction, but also who rejected whom.

We propose that when party A and B commence discussions about a transaction, and party A rejects going ahead with the transaction there will be more learning by party A than B, as party A knows why they have rejected. If, subsequently, a new exchange between the same two actors is attempted, the value that the party A captures is predicted to be greater. We propose that this logic applies in executive search. Specifically, we suggest that an executive search firm will capture more value from searches it conducts with job candidates it already knows when it has previously rejected these candidates and learned about the reasons for those rejections.

\section{H1. Learning in executive search will increase value capture}

In socialisation-based view relationships are often described as enabling flow of social support. For instance, Fernandez et al. (2000) studied referral hiring to shed light on the notion of social capital. Referral hiring in their context consisted of an organisation hiring job candidates who had previous relationships with the existing employees and referred these candidates to the organisation. The authors suggested that through referral hiring organizations were acting as "social capitalists" who invested in the social connections of their employees to generate benefits in the form of better hiring outcomes. The authors found support for their argument of social enrichment, as referral hires whose referrers stayed on the job turned over less than referrals whose referrers resigned. The authors concluded that the benefits to hiring through social networks also flow through previously unobserved socialisation mechanisms.

This landmark study stimulated subsequent studies that examined the exact mechanisms of socialisation and social support in economic transactions. An example is Castilla (2005) who analysed the relationship between referral hiring and employee performance. His analysis showed that performance declined for referrals whose referrer left the organization.

There are grounds to suggest that socialisation/social support processes may have an impact in executive search. The first reason is that at its core, executive search is a referral hiring process, where a search firm refers candidates to the hiring firms. Secondly, executive recruitment is a social matching process where social considerations play a role (Khurana, 2002; Finlay \& Coverdill, 2002; Hamori, 2010; Cappelli, 2008; Groysberg, 2010). It is thus appropriate to consider how flows of social support and associated socialisation impact on the value capture of executive search firms.

Repeated interactions between economic actors engender trust between them (Gulati, 1995; Poppo, Zhou \& Li, 2015; Uzzi, 1997). However, not all interactions generate the same degree of trust. Those interactions in which actors are more constrained due to their roles result in less trust generation (Perrone, Zaheer \& McEvily, 2003). Prior research has shown that the extent to which a role incumbent is autonomous in his/her role (i.e. has discretion over his/her behaviour and decisions while enacting the role) shapes the extent of trust that those that interact with him/her will place in him/her (Perrone et al., 2003). Actors have been shown to trust the role incumbent less when the roles constrain their behaviour more.

Executive search is an appropriate context to study how prior relationships and associated socialisation between actors facilitate value capture. If executive search consultants interact with executives in a less constrained role, more trust will be generated (as per logic above). Specifically, executives are likely to put more trust in executive search consultants working for the firm they have interacted with in the past when these consultants have been less constrained in their roles. Trust should, in turn, reduce the time and effort that the search firm will need to expand on getting executives as job candidates through the process and meeting the hiring firms. We thus propose:

H2. In executive search greater trust will enable greater value capture by the search firms

\section{Method}

The setting for this study is executive search. It is a setting with three actors: executives, executive search firms, 
and firms hiring into executive-level vacancies (hiring firms). Executive search firms play the role of an intermediary as they decide which job candidates they will introduce to their clients, i.e.: the hiring firms. They generate lists of candidates they consider, and then present some candidates to the hiring firms. There is a connection between composition of the consideration set and success of the search: when search firms identify a number of candidates who turn out to be interested in a vacancy, and interesting to the hiring firms, the assignment is likely to complete sooner. When a search assignment finishes sooner, executive search firms capture more value as the fixed fee they receive for a completed search is generated with lower cost (due to a shorter search). In executive search the fee is agreed with the hiring firms at the outset of the process, and payment of the fee is not contingent on successful completion of the process (i.e. someone being hired).

We study value capture at a global executive search firm ("Execo"-a pseudonym), using data from its proprietary electronic records on searches it conducted between January 2005 and May 2009. For prior relationships between the candidates and Execo we use Execo's contact logs for the period between January 2001 and May 2009. Execo places executives in high-level positions across a variety of industries and job functions. The sample used for the study consists of 924 observations (924 search assignments).

We take advantage of the fact that Execo conducted more than one search assignment for several hiring firms during the observation period. We therefore construct a panel dataset where the unit of analysis is each "vacancy by hiring firm". This allows us to estimate the models using the hiring firm fixed effects, and thereby effectively control for unobserved stable characteristics of hiring firms which could result in searches with some hiring firms always being longer or shorter.

The dependent variable is assignment length. We operationalize assignment length as time elapsed between the start date of the assignment, and the date a candidate was placed, or if no one was placed, Execo's last contact with candidates on the assignment. This variable represents an approximation of the costs that the search firm has incurred on a given assignment.

\subsection{Independent Variables}

We used the following independent variables in the study:

- Average number of jobs - not interested: we first added the number of times candidates in the current consideration set rejected invitations for search firm or hiring firm interviews. We added those rejections across the candidates in the consideration set, and then divided that number by the number of candidates (on average over 60; for detail see descriptive statistics below). We followed the same procedure for the other kinds of prior relationships listed below.

- Average number of jobs - not suitable: analogous to average number of jobs - not interested, but in those situations it was when in the past searches the search firm or hiring firm decided to stop pursuing candidates that made it to the consideration set for a current vacancy.

- Average number of general contacts: general contacts mean that an executive and the search firm engage in basic social contact. Such social contact may be a meeting in which the executive and the search consultants exchange information about the state of the industry or the market.

- Average number of client contacts: client contact develops when search consultants, in interactions with executives, play the role of salespeople and client engagement managers.

- Average number of source contacts: source contacts develop when search consultants play the role of market researchers and intelligence gatherers in interactions with executives.

\subsection{Control Variables}

We used the following control variables in the study:

- Margin: this variable is calculated as a ratio between the fee that the hiring firm agreed to pay to the search firm to conduct the search assignment, and the maximum salary for the vacancy. Margin is one of the key parameters used in the industry.

- Vacancy advertised: this is a dummy variable that takes on value 1 if the assignment was advertised, and 0 if it was not.

- Number of candidates in the consideration set: this variable is a count of the number of candidates that were included in the consideration set for the vacancy

- The search firm made a prior placement for the hiring firm: this variable takes on value 1 if Execo has between 2005 and the start date of the focal vacancy placed someone in the hiring firm 
- Execo a preferred supplier to the hiring firm: this variable is a dummy that takes on value 1 if at some point in the past Execo and the hiring firm had a preferred supplier agreement in place.

- Prior search firm relationship with the hiring firm: this variable measures the number of search assignments that the search firm has conducted for the hiring firm between January 2005 and the start date of the focal assignment.

- Maximum salary for the position: the maximum salary for the position is the maximum base salary that the hiring firm is willing to pay the successful candidate. This salary is set at the outset of the search. As the distribution of this variable is skewed, we use the natural $\log$ of the absolute value in the analysis.

- Assignment industry controls: for every assignment the search firm codes the industries in which the hiring firm operates. We include dummies for 16 industries: media, IT, pharmaceuticals, agriculture, finance, professions, leisure, engineering and manufacturing, retail, energy, infrastructure, government, health, education, NGO and other.

- Job function controls: for every assignment the search firm codes the job function(s) that the hired person will occupy. We include dummies for 18 job functions: financial services professional, consultant, board member, $\mathrm{CFO}$, divisional finance director, $\mathrm{CEO}$, divisional managing director, operations director, government, HR director, marketing director, sales director, divisional sales director, legal and governance, non-executive director, pharmaceuticals scientist, management-other, and other.

- Year controls: to control for the potential exogenous effects on the executive labour market (economic cycles, corporate performance etc.) we include year dummies.

\section{Analysis and Results}

Table 1 below summarises the descriptive statistics.

Table 1. Summary of descriptive statistics

\begin{tabular}{|c|c|c|c|c|c|c|c|c|}
\hline \multicolumn{4}{|c|}{$\begin{array}{l}\text { Vacancy level variables ( } \mathrm{N}=924) \text {; only concluded } \\
\text { assignments (i.e. ongoing assignments omitted) }\end{array}$} & \multicolumn{2}{|c|}{$\begin{array}{l}\text { The search firm a preferred } \\
\text { supplier to the hiring firm } \\
(1=y e s)\end{array}$} & \multirow{2}{*}{$\begin{array}{l}.114 \\
.259\end{array}$} & \multirow{2}{*}{$\begin{array}{l}.101 \\
.298\end{array}$} & \multirow{2}{*}{$\begin{array}{l}0.540 \\
0.060\end{array}$} \\
\hline Variable & $\begin{array}{l}\text { No on } \\
\text { placed } \\
(\mathrm{N}=463)\end{array}$ & $\begin{array}{l}\text { Someone } \\
\text { placed } \\
(\mathrm{N}=461)\end{array}$ & p-value & $\begin{array}{l}\text { Average number of jobs } \\
\text { interested }\end{array}$ & not & & & \\
\hline $\begin{array}{l}\text { Assignment length } \\
\text { (months) }\end{array}$ & 8.336 & 7.896 & 0.254 & $\begin{array}{l}\text { Average number of jobs } \\
\text { suitable }\end{array}$ & : not & .343 & .389 & 0.025 \\
\hline $\begin{array}{l}\text { Number of the search } \\
\text { firm's prior assignments } \\
\text { for the hiring firm }\end{array}$ & 1.645 & 1.180 & 0.006 & $\begin{array}{l}\text { Average number of jobs } \\
\text { outcome unknown }\end{array}$ & the & .062 & .066 & 0.470 \\
\hline Vacancy salary & 160,217 & 154,627 & 0.322 & $\begin{array}{l}\text { Average number of ge } \\
\text { contacts }\end{array}$ & neral & .553 & .623 & 0.108 \\
\hline $\begin{array}{l}\text { Vacancy } \quad \text { advertised } \\
(1=\text { yes })\end{array}$ & .276 & .436 & 0.000 & $\begin{array}{l}\text { Average number of } \\
\text { contacts }\end{array}$ & lient & .906 & $\begin{array}{l}1.27 \\
2\end{array}$ & 0.015 \\
\hline $\begin{array}{l}\text { Margin } \quad \text { (fee/vacancy } \\
\text { salary) }\end{array}$ & .322 & .326 & 0.516 & $\begin{array}{l}\text { Average number of } \mathrm{s} \\
\text { contacts }\end{array}$ & urce & .850 & .951 & 0.112 \\
\hline $\begin{array}{l}\text { Number of candidates in } \\
\text { the consideration set } \\
\text { The search firm made a } \\
\text { prior placement for the } \\
\text { hiring firm ( } 1=y e s)\end{array}$ & $\begin{array}{l}60.086 \\
.546\end{array}$ & $\begin{array}{l}68.572 \\
.518\end{array}$ & $\begin{array}{l}0.016 \\
0.394\end{array}$ & & & & & \\
\hline \multicolumn{4}{|l|}{ Job industry (\%) } & \multicolumn{5}{|l|}{ Job function (\%) } \\
\hline Media & & structure & 6.28 & $\begin{array}{ll}\text { Financial } & \text { services } \\
\text { professional } & \end{array}$ & $\begin{array}{l}10.3 \\
9\end{array}$ & $\begin{array}{l}\text { Ma } \\
\text { dire }\end{array}$ & $\begin{array}{l}\text { eting } \\
\text { tor }\end{array}$ & 7.14 \\
\hline IT & & ernment & 9.42 & Consultant & 1.08 & Sal & director & 3.35 \\
\hline Pharmaceuticals & & & 0.76 & Board member & 4.33 & $\begin{array}{l}\text { Div } \\
\text { sale }\end{array}$ & $\begin{array}{l}\text { ional } \\
\text { director }\end{array}$ & 2.38 \\
\hline Agriculture & & cation & 0.32 & $\mathrm{CFO}$ & 7.03 & $\begin{array}{l}\text { Leg } \\
\text { gov }\end{array}$ & and & 5.84 \\
\hline
\end{tabular}




\begin{tabular}{|c|c|c|c|c|c|c|c|c|}
\hline Finance & & 33.87 & $\mathrm{NGO}$ & 1.30 & $\begin{array}{l}\text { Divisional finance } \\
\text { director }\end{array}$ & 3.25 & $\begin{array}{l}\text { Non-executiv } \\
\text { e director }\end{array}$ & 1.41 \\
\hline Professions & & 8.23 & Other & 3.79 & $\mathrm{CEO}$ & 7.14 & $\begin{array}{l}\text { Pharmaceutic } \\
\text { als scientist }\end{array}$ & 1.19 \\
\hline Leisure & & 6.28 & Missing & 0.00 & $\begin{array}{l}\text { Divisional managing } \\
\text { director }\end{array}$ & $\begin{array}{l}13.7 \\
4\end{array}$ & $\begin{array}{l}\text { Management- } \\
\text { other }\end{array}$ & $\begin{array}{l}21.0 \\
0\end{array}$ \\
\hline $\begin{array}{l}\text { Engineering } \\
\text { manufacturing }\end{array}$ & and & 12.23 & & & Operations director & 2.71 & Other & $\begin{array}{l}14.6 \\
1\end{array}$ \\
\hline Retail & & 15.26 & & & Government & 4.00 & Missing & 0.32 \\
\hline Energy & & 2.16 & & & HR director & 4.65 & & \\
\hline
\end{tabular}

On average the vacancy salary is $£ 160,000$ for vacancies where no one was placed (N=463, 50\% of the sample) and $£ 155,000$ where someone was placed $(\mathrm{N}=461,50 \%$ of the sample). This means that the vacancies studied in this article are at the very high end of the labour market.

Execo conducted 1.64 search assignments for the hiring firm before the assignments in the sample that ended up with no placement, and 1.18 for those that ended in placement. It included on average 60 candidates on its internal list of potentially suitable candidates for searches that didn't result in a placement, and 68 for searches that did.

In terms of the search assignment industry, over a third of the assignments were in the finance industry (33.87\%), followed by retail (15.26\%) and engineering and manufacturing (12.23\%). The most represented job functions were management-other $(21.00 \%)$, divisional managing director $(13.74 \%)$, and financial services professional (10.39\%). CEO searches represented around $7 \%$ of the sample.

We first analysed whether assignments that concluded successfully (i.e. with someone placed) differed in some way from the unsuccessful ones (i.e. no-one placed). The difference in the length is not statistically significant. The average length of the former is 8.33 months, while the latter is 7.89 months. The assignments that were advertised and those with more candidates in the consideration set were more likely to result in a placement. The assignments that ended in a placement also included candidates who have been rejected more in the past, and who had more contacts in the client role with Execo. These results underline that not all kinds of prior relationships are likely to lead to a successful completion of an assignment.

We then examined how different kinds of prior relationships affect the length of the assignment (and thereby the value that is captured by the search firm). We estimated the OLS models in Table 2.

Table 2. OLS regressions predicting the length of the search assignment

\begin{tabular}{|c|c|c|c|}
\hline Variable & $\begin{array}{l}\text { Model } 1 \text { (hiring } \\
\text { firm fixed effects) }\end{array}$ & $\begin{array}{l}\text { Model } 2 \text { (hiring } \\
\text { firm fixed effects) }\end{array}$ & $\begin{array}{l}\text { Model } 3 \text { (hiring } \\
\text { firm fixed effects) }\end{array}$ \\
\hline \multirow[t]{2}{*}{ Margin (fee/vacancy salary) } & 3.2731 & 2.6852 & 3.0015 \\
\hline & [3.019] & [3.089] & [3.106] \\
\hline \multirow[t]{2}{*}{ Number of candidates in the consideration set } & $0.0271 * *$ & $0.0265 * *$ & $0.0271 * *$ \\
\hline & {$[0.005]$} & {$[0.005]$} & [0.005] \\
\hline \multirow[t]{2}{*}{ Vacancy salary $(\ln )$} & $1.4148+$ & 1.1193 & 1.3667 \\
\hline & [0.823] & [0.917] & [0.904] \\
\hline \multirow[t]{2}{*}{ Vacancy advertised (1=yes) } & -0.5407 & -0.6247 & -0.3274 \\
\hline & {$[0.750]$} & {$[0.796]$} & {$[0.846]$} \\
\hline \multirow{2}{*}{$\begin{array}{l}\text { Number of the search firm's prior assignments for the } \\
\text { hiring firm }\end{array}$} & $-0.2100+$ & $-0.2329+$ & $-0.2342+$ \\
\hline & {$[0.118]$} & [0.124] & [0.126] \\
\hline \multirow{2}{*}{$\begin{array}{l}\text { The search firm made a prior placement for the hiring } \\
\text { firm (1=yes) }\end{array}$} & $2.2142^{*}$ & $1.9575+$ & $2.2069^{*}$ \\
\hline & {$[1.020]$} & [1.023] & [1.008] \\
\hline \multirow{2}{*}{$\begin{array}{l}\text { The search firm a preferred supplier to the hiring firm } \\
(1=y e s)\end{array}$} & 0.1722 & 0.2503 & 0.0683 \\
\hline & {$[0.411]$} & {$[0.455]$} & [0.483] \\
\hline \multirow[t]{2}{*}{ Someone placed (1=yes) } & -0.0204 & -0.0905 & 0.8336 \\
\hline & [0.648] & [0.647] & [0.835] \\
\hline \multirow[t]{2}{*}{ Average number of jobs: not interested } & & -2.9188 & $-3.5443+$ \\
\hline & & {$[1.826]$} & [2.023] \\
\hline
\end{tabular}




\begin{tabular}{|c|c|c|c|}
\hline \multicolumn{2}{|l|}{ Average number of jobs: not suitable } & -0.8869 & 0.4911 \\
\hline & & [1.194] & [1.717] \\
\hline \multirow{2}{*}{\multicolumn{2}{|c|}{ Average number of jobs: the outcome unknown }} & 4.4809 & $5.8230+$ \\
\hline & & {$[3.440]$} & [3.472] \\
\hline \multirow{2}{*}{\multicolumn{2}{|c|}{ Average number of client contacts }} & 0.9199 & 0.9459 \\
\hline & & {$[1.178]$} & {$[1.153]$} \\
\hline \multirow{2}{*}{\multicolumn{2}{|c|}{ Average number of general contacts }} & -0.0777 & -0.0623 \\
\hline & & {$[0.217]$} & {$[0.215]$} \\
\hline \multirow[t]{2}{*}{ Average number of source contacts } & & 0.2672 & 0.2156 \\
\hline & & {$[0.488]$} & {$[0.482]$} \\
\hline \multirow{2}{*}{\multicolumn{3}{|c|}{ Someone placed $*$ number of jobs: not interested }} & 2.0030 \\
\hline & & & [1.732] \\
\hline \multicolumn{3}{|l|}{ Someone placed $*$ number of jobs: not suitable } & $-4.0843^{*}$ \\
\hline & & & [1.844] \\
\hline \multirow[t]{2}{*}{ Constant } & -13.6087 & -10.9938 & -14.9543 \\
\hline & [10.519] & [11.119] & [10.899] \\
\hline N observations (vacancies) & 924 & 924 & 924 \\
\hline $\mathrm{N}$ of hiring firms & 489 & 489 & 489 \\
\hline R-squared & 0.178 & 0.186 & 0.194 \\
\hline
\end{tabular}

Note. $+\mathrm{p}<0.10, * \mathrm{p}<0.05, * * \mathrm{p}<0.01$.

All tests are two-tailed.

Robust standard errors are clustered by the hiring firm.

All models include the following controls: assignment industry, job function, year dummies.

Number of jobs and contacts is measured as an average per candidate in the consideration set.

Reported R-squared is within R-squared.

Model 1 includes the controls. The assignments with a larger number of candidates in the consideration set take longer to conclude. A more surprising finding is that the assignments take longer when the search firm has already placed someone in the hiring firm. We do not have information on why this may be so. One potential explanation might be that once the search firm places someone in the hiring firm, it gets the opportunity to work on more complex and potentially more profitable searches, which may also take longer.

Model 2 includes the relationship variables. It turns out that none of the relationship variables significantly impact the length of all assignments. In Model 3 we thus consider whether the impact of the prior relationships may differentially affect the length of the successful versus unsuccessful assignments. We include the interaction of the "someone placed" variable with the prior relationships. In the interest of brevity we are presenting the results with the interactions of "someone placed" with the average number of jobs not interested, and not suitable. The results are the same if we include the full set of the interaction terms with other relationship variables (and none of the other interaction terms are significant).

Model 3 contains an interesting result: the assignments with candidates who have been rejected before, and that result in a placement, are shorter than the other assignments where someone was placed. According to this result prior relationships with the candidates, built through the search firm/the hiring firm rejections, enable the search firm to capture more value in the search assignments.

This result requires careful interpretation from the perspective of our hypotheses. In hypothesis 1 we predicted that more learning in executive search will increase value capture, while in hypothesis 2 we predicted that greater trust in executive search will enable greater value capture by the search firms. Amongst the relationship variables most closely corresponding to the notion of learning are two rejection variables-"not interested" and "not suitable". Model 3 indicates the latter variable has a significant effect on the length of searches ending in a placement.

The notion of trust, on the other hand, is most closely captured in general relationships. In general relationships search consultants are least constrained in their role as they do not have a particular mandate from the search firm to achieve something from that interaction, as they do in other interactions (candidate, client and source). As per trust literature referenced above, lesser role constraint when a search consultant performs general role should engender more trust in candidates for vacancies, which should make dealing with them in subsequent searches less demanding and in turn should shorten searches with those candidates. We don't find a significant effect of 
that variable.

Our results thus suggest that in the context of executive search value capture is affected by learning, but not trust. This is indicated by the significant effect of the interaction term between "someone placed" and "number of jobs candidates have been rejected for in the past". It is worth noting that this effect is not driven by just general learning, but rather specific learning about candidates that comes from rejecting them. This effect was not present in searches that ended without a placement, which is consistent with our logic: the latter searches lasted longer and meant the search firm captured less value in them than in successful searches.

As per magnitude of the effect, the coefficient on the interaction term is -4.0843 . Main coefficient on "not suitable" is 0.49 , meaning that if the number of jobs not suitable per person goes up by 1 , the assignment is on average longer for 0.5 months. However, in assignments that end in placement it is 3.5 months shorter. Since the average length of searches that ended in a placement in this sample is 7.89 months, reduction in length by 3.5 months means such assignments will be $45 \%$ shorter. Value captured due to relationship-based learning can thus be almost half greater than when there is absence of such learning.

\section{Discussion}

The theme of this article is economic value. We address the question of how does economic value get distributed among participants in transactions. We specifically focus on how pre-existing relationships between actors participating in a transaction shape value capture.

We have focused on the effect of relationships on value capture because the extant literature demonstrated that: 1) relationships contribute to generation of economic value (Granovetter, 1973; Ferriani, Fonti, \& Corrado, 2013; Uzzi, 1996, 1997, 1999; Gulati, 1995; Fernandez et al., 2000; Castilla, 2005; Petersen et al., 2000); and 2) division of value between participants in transactions may be uneven and some parties may capture more (Fernandez-Mateo, 2007; Bidwell \& Fernandez-Mateo, 2010). We built on this literature and developed hypotheses that suggest that value capture by one party will be greater when that party learns more in the previous relationships and when those relationships lead to development of trust.

We have examined value capture in the context of executive search. We defined value capture as proportional to length of a search assignment. We then analysed the relationship between five types of pre-existing candidate/search firm relationships and length of search. We predicted that value capture will increase with 1) greater learning by the search firm about candidates and 2) greater trust development through relationships. We conducted fixed effects analysis which enabled us to control for explanations that would relate the results to stable differences between hiring firms. We also controlled for a number of other potential explanations, most significant among them that value capture is dependent on the fee that the search firm gets for the search. We didn't find support for that explanation in our data.

We found that length of the search is significantly reduced when the candidates on the list were more frequently rejected in the past by the search firm. This effect holds for searches that resulted in a placement. We interpret this as evidence of learning in relationships that supports value capture (with delayed effect). We haven't found the hypothesised effect of trust in the data.

These findings provide four contributions to the literature on value capture: first, they provide further evidence that value capture is enabled by prior relationships between actors in the transaction. In that way the article extends the literature on value creation and value capture through relationships. Second, the findings suggest that social support/trust and learning that flow through relationships may have a distinct effect on the ability of actors to capture value; in some contexts, such as our context of executive search, learning may be the key to value capture. This has implications for how we understand the role of social context in transactions. A macro-social context such as institutional rules may shape what is acceptable and desirable in transactions and in that way impact upon the value actors can capture (see Khurana, 2002). At micro level, direct one-to-one relationships between actors can facilitate value capture, as they enable one party to learn a great deal about how to work with the other party to capture value.

Third, value capture may be a delayed effect of relationships developed over a period of time. Much of the literature referenced above invokes delayed effects of relationships, and in this article we provide evidence for value capture. Fourth, the results suggest that value may be captured in situations that are not strictly competitive, on the basis of a relationship with a non-competitor. We have shown that value capture may take place through a non-competitive process, while it has traditionally been portrayed as an outcome of a competitive process (Porter, 1980). A classic example of value capture in relationships is brokerage (Burt, 1992; Gould \& Fernandez, 1989; Fernandez \& Gould, 1994), where broker captures value by engineering competition for resources between the 
brokered parties and playing them off.

This study has limitations that are worth explicating as they may suggest future directions of research. One limitation is that we are unable to measure learning and accumulation of trust directly, but need to infer it from descriptions of relationships given to us by our informants from Execo. Future research could try to measure those directly, using archival data for learning and surveys for trust. Direct data might provide some insight into why trust or social support that flows through relationships may not have a significant impact on value capture. Another limitation is that we lack detailed data that would give us an indication of how exactly learning impacts upon value capture. This is a question of interest for economic sociology and organisational theory, as well as business strategy and economics. The effect found in this study might prompt scholars in those other areas to seek data that would help shed light on this interesting and important phenomenon. A third limitation is that we have little insight into why the effect of relationships is strong in searches that end in placement, but not in the ones that do not. This opens a broader question of the scope conditions of the effect found in our study. We demonstrated the existence of the effect; future research might provide evidence around the conditions that stimulate or hinder it, which would be a valuable contribution to our understanding of value capture and the role of relationships within it.

\section{References}

Bidwell, M., \& Fernandez-Mateo, I. (2010). Relationship duration and returns to brokerage in the staffing sector. Organization Science, 21(6), 1141-1158. http://dx.doi.org/10.1287/orsc.1090.0509

Burt, R. S. (1992). Structural holes: The social structure of competition. Cambridge, MA: Harvard University Press.

Cappelli, P. (2008). Talent on demand: Managing talent in an age of uncertainty. Boston, MA: Harvard Business School Press.

Castilla, E. J. (2005). Social networks and employee performance in a call center. American Journal of Sociology, 110(5), 1243-1283. http://dx.doi.org/10.1080/09585192.2015.1020441

Fernandez, R. M., \& Gould, R. V. (1994). A dilemma of state power-brokerage and influence in the national-health policy domain. American Journal of Sociology, 99(6), 1455-1491. http://dx.doi.org/10.1086/230451

Fernandez, R. M., Castilla, E. J., \& Moore, P. (2000). Social capital at work: Networks and employment at a phone center. American Journal of Sociology, 105(5), 1288-1356. http://dx.doi.org/10.1086/210432

Fernandez-Mateo, I. (2007). Who pays the price of brokerage? Transferring constraint through price setting in the staffing sector. American Sociological Review, 72(2), 291-317. http://dx.doi.org/10.1177/000312240707200208

Ferriani, S., Fonti, F., \& Corrado, R. (2013). The social and economic bases of network multiplexity: Exploring the emergence of multiplex ties. Strategic Organization, 11(1), 7-34. http://dx.doi.org/10.1177/1476127012461576

Finlay, W., \& Coverdill, J. (2002). Headhunters: Matchmaking in the labor market. Ithaca, NY: Cornell University Press.

Gould, R. V., \& Fernandez, R. M. (1989). Structures of mediation: A formal approach to brokerage in transaction networks. Sociological Methodology, 19, 89-126. http://dx.doi.org/ 10.2307/270949

Granovetter, M. S. (1973). Strength of weak ties. American Journal of Sociology, 78(6), 1360-1380. http://dx.doi.org/10.1086/225469

Groysberg, B. (2010). Chasing stars: The myth of talent and the portability of performance. Princeton, NJ: Princeton University Press. http://dx.doi.org/10.1515/9781400834389

Gulati, R. (1995). Does familiarity breed trust? The implications of repeated ties for contractual choice in alliances. Academy of Management Journal, 38(1). http://dx.doi.org/10.2307/256729

Hamori, M. (2010). Who gets headhunted-and who gets ahead? The impact of search firms on executive careers. Academy of Management Perspectives, 24(4), 46-59.

Khurana, R. (2002). Searching for a corporate savior: The irrational quest for charismatic CEOs. Princeton, NJ: Princeton University Press. http://dx.doi.org/10.1515/9781400841097

Perrone, V., Zaheer, A., \& McEvily, B. (2003). Free to be trusted? Organizational constraints on trust in 
boundary spanners. Organization Science, 14(4), 422-439. http://dx.doi.org/10.1287/orsc

Petersen, T., Saporta, I., \& Seidel, M. D. L. (2000). Offering a job: Meritocracy and social networks. American Journal of Sociology, 106(3), 763-816. http://dx.doi.org/ 10.1086/318961

Podolny, J. M., \& Baron, J. N. (1997). Resources and relationships: Social networks and mobility in the workplace. American Sociological Review, 62(5), 673-693. http://dx.doi.org/10.2307/2657354

Podolny, J. M. (2001). Networks as pipes and prisms of the market. American Journal of Sociology, 107(1), 33-60. http://dx.doi.org/ 10.1086/323038

Poppo, L., Zhou, Z., \& Li, J. (2015). When can you trust "trust"? Calculative trust, relational trust, and supplier performance. Strategic Management Journal. http://dx.doi.org/10.1002/smj.2374

Porter, M. (1980). Competitive Strategy: Techniques for analyzing industries and competitors. New York: Free Press.

Uzzi, B. (1996). The sources and consequences of embeddedness for the economic performance of organizations: The network effect. American Sociological Review, 61(4), 674-698. http://dx.doi.org/10.2307/2096399

Uzzi, B. (1997). Social structure and competition in interfirm networks: The paradox of embeddedness. Administrative Science Quarterly, 42(1), 35-67. http://dx.doi.org/ 10.2307/2393808

Uzzi, B. (1999). Embeddedness in the making of financial capital: How social relations and networks benefit firms seeking financing. American Sociological Review, 64, 481-505. http://dx.doi.org/10.2307/2657252

Yakubovich, V. (2005). Weak ties, information, and influence: How workers find jobs in a local Russian labor market. American Sociological Review, 70(3), 408-421. http://dx.doi.org/ 10.1177/000312240507000303

\section{Copyrights}

Copyright for this article is retained by the author(s), with first publication rights granted to the journal.

This is an open-access article distributed under the terms and conditions of the Creative Commons Attribution license (http://creativecommons.org/licenses/by/3.0/). 